\title{
A Novel Cellulase Produced by a Newly Isolated Trichoderma virens
}

\author{
Rong Zeng ${ }^{1,+}{ }^{\dagger}$, Xiao-Yan Yin ${ }^{2,+}{ }^{+}$, Tao Ruan ${ }^{2}$, Qiao Hu ${ }^{2}$, Ya-Li Hou ${ }^{2}$, Zhen-Yu Zuo ${ }^{2}$, Hao Huang ${ }^{2}$ \\ and Zhong-Hua Yang ${ }^{2, *}$ \\ 1 College of Chemistry and Chemical Engineering, Hubei University, Wuhan 430062, China; \\ rongzengce@163.com \\ 2 College of Chemical Engineering and Technology, Wuhan University of Science and Technology, \\ Wuhan 430081, China; yinxiaoyan0516@163.com (X.-Y.Y.); 15671627439@163.com (T.R.); \\ huqiao294873270@163.com (Q.H.); houyali88@163.com (Y.-L.H.); zuozhenyu@wust.edu.cn (Z.-Y.Z.); \\ hhzy310@163.com (H.H.) \\ * Correspondence: yangzh@wust.edu.cn; Tel.: +86-27-8656-3448 \\ + The authors contributed equally to this work and should be considered co-first authors. \\ Academic Editor: Daniel G. Bracewell \\ Received: 21 January 2016; Accepted: 15 April 2016; Published: 19 April 2016
}

\begin{abstract}
Screening and obtaining a novel high activity cellulase and its producing microbe strain is the most important and essential way to improve the utilization of crop straw. In this paper, we devoted our efforts to isolating a novel microbe strain which could produce high activity cellulase. A novel strain Trichoderma virens ZY-01 was isolated from a cropland where straw is rich and decomposed, by using the soil dilution plate method with cellulose and Congo red. The strain has been licensed with a patent numbered ZL 201210295819.6. The cellulase activity in the cultivation broth could reach up to $7.4 \mathrm{IU} / \mathrm{mL}$ at a non-optimized fermentation condition with the newly isolated T. virens ZY-01. The cellulase was separated and purified from the T. virens culture broth through $\left(\mathrm{NH}_{4}\right)_{2} \mathrm{SO}_{4}$ fractional precipitation, anion-exchange chromatography and gel filtration chromatography. With the separation process, the CMC specific activity increased from $0.88 \mathrm{IU} / \mathrm{mg}$ to $31.5 \mathrm{IU} / \mathrm{mg}$ with 35.8 purification fold and $47.04 \%$ yield. Furthermore, the enzymatic properties of the cellulase were investigated. The optimum temperature and $\mathrm{pH}$ is $50{ }^{\circ} \mathrm{C}$ and $\mathrm{pH} 5.0$ and it has good thermal stability. $\mathrm{Zn}^{2+}, \mathrm{Ca}^{2+}$ and $\mathrm{Mn}^{2+}$ could remarkably promote the enzyme activity. Conversely, $\mathrm{Cu}^{2+}$ and $\mathrm{Co}^{2+}$ could inhibit the enzymatic activity. This work provides a new highly efficient $T$. virens strain for cellulase production and shows good prospects in practical application.
\end{abstract}

Keywords: Trichoderma virens; cellulase; strain isolation; straw; biomass

\section{Introduction}

With the development of agriculture, cellulose-rich straws from cropland have become one of the largest amounts of biomass. They should be comprehensively utilized as biological resources. Unfortunately, most crop straws, such as wheat straw and rice straw, are directly burned in cropland, which has caused serious atmospheric pollution in China [1]. If biological resources that are prevented from being directly burned in cropland can be utilized as carbohydrates, then the atmospheric pollution can be avoided and a huge amount of carbohydrates, such as fermentable sugars, can be provided. It is well known that the main component of straw is cellulose, which is the most common source of renewable carbon and energy on earth. Cellulose could be efficiently degraded to fermentable sugars with conventional biological processes. The fermentable sugars are the most important platform material, which could be further converted to ethanol (biofuel), single cell protein (SCP) and other chemicals by biotechnology [2-4]. In the process route, a high activity of cellulase is the key factor to this biological process of straw utilization as biological resources [5-7]. Screening and obtaining 
a novel high activity cellulase and its producing microbe strain is always the most important and essential way to improve the straw utilization. Moreover, cellulase has a very broad application in other fields such as food processing, oil extraction, agricultural industries, brewery, animal feed, textile and other fields like laundry, pulp, paper, detergent industry [8-12].

Cellulase is mainly produced by microbes, especially fungus, such as Trichoderma, Aspergillus and Penicillium. Nowadays, more and more Trichoderma fungi have been screened; however, there exists a lower-yield problem, so it is important to screen a strain that produces cellulase efficiently.

In this paper, we devoted our efforts to isolate a novel microbe strain which can produce high activity cellulase. Furthermore, the enzymatic properties of this new cellulase will also be evaluated.

\section{Materials and Methods}

\subsection{Material and Media}

The soil samples were obtained from land areas where straw is rich and some straw was decomposed. We collected soil samples from a wheat field $\left(33^{\circ} 36^{\prime} 41^{\prime \prime} \mathrm{N}\right.$ and $116^{\circ} 56^{\prime} 17^{\prime \prime} \mathrm{E}$, Suzhou county, Anhui province, China), Yangtze River riverbank $\left(30^{\circ} 38^{\prime} 14^{\prime \prime} \mathrm{N}\right.$ and $114^{\circ} 22^{\prime} 4^{\prime \prime} \mathrm{E}$, Wuhan City, Hubei province, China), and a paper mill $\left(30^{\circ} 27^{\prime} 3^{\prime \prime} \mathrm{N}, 114^{\circ} 11^{\prime} 59^{\prime \prime} \mathrm{E}\right.$, Wuhan City, Hubei province, China).

The following mediums were used for enrichment, screening, identification and cultivation process. the enrichment medium was used to enrich the microbe, and it was composed of (in $\mathrm{g} / \mathrm{L}$ ): oatmeal extract (oatmeal $3.5 \mathrm{~g}$ adding water $30 \mathrm{~mL}$ and boil 20-30 $\mathrm{min}$ then filter to obtain the filtrate), agar 1.5, crystal violet 0.5 , deionized water $100 \mathrm{~mL}$. The Congo red medium was used to screen the target strain as the screening medium, it was composed of (in g/L): $\mathrm{KH}_{2} \mathrm{PO}_{4}$ 1.0, $\mathrm{NaNO}_{3} 3.0, \mathrm{KCl} 0.5$, $\mathrm{MgSO}_{4} \cdot 7 \mathrm{H}_{2} \mathrm{O}$ 0.5, $\mathrm{FeSO}_{4} \cdot 7 \mathrm{H}_{2} \mathrm{O}$ 0.01, CMC.Na 15, Agar 15-20 and Congo red 0.2. The identification medium was used to identify the target strain, which was composed of (in $\mathrm{g} / \mathrm{L}$ ): $\mathrm{NaNO}_{3} 3.0, \mathrm{MgSO}_{4}$ $0.5, \mathrm{~K}_{2} \mathrm{HPO}_{4} 1.0, \mathrm{KCl} 0.5, \mathrm{FeSO}_{4} 0.01$, sucrose or glucose 30.0. The fermentation medium was used to culture the target strain and produce cellulase, it was composed of (in $\mathrm{g} / \mathrm{L}$ ): yeast extract 1, CMC.Na 5 , $\mathrm{NaCl} 20, \mathrm{~K}_{2} \mathrm{HPO}_{4} 0.5$ and $\mathrm{MgSO}_{4} \cdot 7 \mathrm{H}_{2} \mathrm{O} 0.5$.

\subsection{Screening the Microbe for Cellulase and Microbe Identification}

The soil sample ( $2.0 \mathrm{~g}$ ) was suspended in $20 \mathrm{~mL}$ of sterile distilled water. Then $0.5 \mathrm{~mL}$ supernatant was inoculated on enrichment medium plates with coating inoculation, and cultured for three days at $30{ }^{\circ} \mathrm{C}$. The colonies growing in the enrichment medium plates were inoculated in the Congo red medium plate with inoculating needle and further cultured on the third day at $30^{\circ} \mathrm{C}$. The colonies growing on the Congo red plate were the microbes which can excrete cellulase. The diameters of the colony and hydrolyzed circle can indicate the microbe's ability to produce cellulase [10]. The selected colonies were further purified by culture in new Congo red medium plate.

Morphological and molecular identification of the isolated microbes were done according to the Fungal Identification Manual [13]. The identification medium was used to culture the screened strain. A light microscope was used to observe its morphological features. Genomic DNA for molecular identification of the strain was extracted using the modified benzyl chloride method [14]. In order to identify the isolated microbe, the $18 \mathrm{~S}$ rDNA was cloned by PCR (Initialization at $94{ }^{\circ} \mathrm{C}$ for $5 \mathrm{~min}$, Denaturation at $94{ }^{\circ} \mathrm{C}$ for $30 \mathrm{~s}$, Annealing at $54{ }^{\circ} \mathrm{C}$ for $1 \mathrm{~min}$, Extension at $72{ }^{\circ} \mathrm{C}$ for $90 \mathrm{~s}, 30$ cycles, Final elongation at $72{ }^{\circ} \mathrm{C}$ for $10 \mathrm{~min}, 4^{\circ} \mathrm{C}$ to the end, PCR in $25 \mu \mathrm{L}$ reaction system with pfu DNA polymerase) with the primers (Forward: $5^{\prime}$-GTAGTCATATGCTTGTCTC-3' ${ }^{\prime}$, Reverse: $5^{\prime}$-TCCGCAGGTTCACCTACGGA-3'). The PCR-amplified products were purified by Gel Extraction kit (Omega Bio-Tek, Norcross, GA, USA) and sequenced by Sangon Biotech (Shanghai, China). The 18S rDNA was compared with sequences in nucleotide database (NCBI) using the BLAST algorithm. Multiple sequence alignment was carried out with CLUSTALW (Conway Institute UCD, Dublin, Ireland) multiple sequence alignment. The neighbour-joining phylogenetic analysis was constructed 
with MEGA v.5.0 software (Center for Evolutionary Medicine and Informatics, The Biodesign Institute, Tempe, AZ, USA).

\subsection{Purification of the Cellulase from the Newly Isolated Microbe Culture Broth}

The cellulase was produced by the newly isolated strain with fermentation medium at $30{ }^{\circ} \mathrm{C}$ for 4 days. The crude enzyme extraction was collected by centrifuging the cultivation broth, since cellulase is an extracellular enzyme. It was further purified by fractionation salting out ( $50 \%-70 \%$ saturation of ammonium sulfate), anion exchange chromatography (DEAE Sepharose Fast Flow, elution with $0-0.8 \mathrm{M} \cdot \mathrm{NaCl}$ ) and gel filtration chromatography (SephadexG-75). After purification, the purified product was assayed by SDS-PAGE.

\subsection{Evaluation of Enzymatic Properties}

The following enzymatic properties of the cellulase produced by the newly isolated microbe were evaluated. The optimum $\mathrm{pH}$ and $\mathrm{pH}$ stability, the optimum temperature and thermal stability and effects of metal ions to the enzymatic activity were investigated. Er mixed $0.5 \mathrm{~mL}$ enzyme with $0.5 \mathrm{~mL}$ substrate containing $0.05 \%(w / v)$ CMC-Na in citric acid buffer and incubated the mixture $(\mathrm{pH}=5.0)$ for $1 \mathrm{~h}$. The temperature range was from $30{ }^{\circ} \mathrm{C}$ to $90^{\circ} \mathrm{C}$, and $\mathrm{pH}$ was range from 2 to 9 , and the concentration of metal ions was $0.01 \mathrm{~mol} / \mathrm{L}$. After incubation, we measured the cellulase activity, as described below.

\subsection{Cellulase Activity Assay}

The activity of the cellulase was assayed with CMC-Na activity measurement [15]. An enzyme sample of $0.5 \mathrm{~mL}$ was added into $1.5 \mathrm{~mL}$ of the reaction mixture (containing $0.05 \%(w / v) \mathrm{CMC} \cdot \mathrm{Na}$ with pH 5.0 citric acid buffer) and incubated at $50^{\circ} \mathrm{C}$ for $1 \mathrm{~h}$. Then the reducing sugar released by the reaction was determined by DNS method. One unit of the CMC enzyme activity was defined as the amount of enzyme that catalyzed to produce $1 \mu \mathrm{mol}$ of reduced sugar per minute with the reduction of CMC-Na.

\section{Results}

\subsection{Isolation of Microbe for Cellulase and Microbe Identification}

The purpose of isolation was to obtain a microbial strain that possessed ability to produce high activity cellulase. With the isolation procedure, four microbial strains were obtained and tested for cellulase activity, which can be released from cellulase to hydrolysis the CMC.Na and formed an obvious hydrolyzed circle. Table 1 describes the physiological characteristics of the isolated strains.

Table 1. Isolated strains for cellulase production.

\begin{tabular}{ccccc}
\hline Strain $^{1}$ & $\begin{array}{c}\text { Colony } \\
\text { Diameter/cm }\end{array}$ & $\begin{array}{c}\text { Hydrolysised Circle } \\
\text { Diameter/cm }\end{array}$ & Colony Color & Colony Morphology \\
\hline ZY-01 & $2.30 \pm 0.22$ & $4.32 \pm 0.26$ & $\begin{array}{c}\text { Early phase white, } \\
\text { Anaphase green }\end{array}$ & $\begin{array}{c}\text { Edge irregular dentatus, } \\
\text { Surface filiform }\end{array}$ \\
\hline ZY-02 & $1.87 \pm 0.41$ & $2.82 \pm 0.38$ & white & $\begin{array}{c}\text { Edge irregular dentatus, } \\
\text { Surface filiform }\end{array}$ \\
\hline ZY-03 & $2.12 \pm 0.49$ & $3.02 \pm 0.37$ & $\begin{array}{c}\text { Front milk white, } \\
\text { Back yellow }\end{array}$ & $\begin{array}{c}\text { Edge irregular dentatus, } \\
\text { Surface filiform }\end{array}$ \\
\hline ZY-04 & $3.27 \pm 0.43$ & fuzzy & $\begin{array}{c}\text { Front yellow-white, } \\
\text { Back red }\end{array}$ & $\begin{array}{c}\text { Edge irregular dentatus, } \\
\text { Surface smooth }\end{array}$ \\
\hline $\begin{array}{l}1 \\
\text { ZY-01: soil sample from wheat field, ZY-02 and ZY-03: soil sample from Yangtze River riverside, ZY-04: soil }\end{array}$ \\
sample from paper mill.
\end{tabular}

In terms of the diameter size of the colony and hydrolysised circle that appeared on the plates, strain $\mathrm{ZY}-01$ is the best strain for cellulase production. Since the strain possesses more cellulase 
production ability, then more cellulase activity can be released to hydrolysis of the CMC-Na and a larger hydrolysised circle and colony were formed. It can be confirmed that ZY-01 is a good high-producing strain. The cellulase production ability of this newly isolated ZY-01 strain was tested. The cellulase activity $7.4 \mathrm{IU} / \mathrm{mL}$ was obtained at a non-optimized fermentation condition.

The colony morphology and the morphological features of mycelium by light microscope both indicated that the screened ZY-01was a fungi. To further identify strain ZY-01, its 18S rDNA region was cloned by PCR and sequenced. Its nucleotide blast analysis was conducted in NCBI to find homologous sequences. The neighbor-joining phylogenetic tree, Figure 1, was constructed with these homologous sequences. The results show that strain ZY-01 is a Trichoderma virens. Furthermore, the morphological identification experiments also confirm that it is a T. virens according to the Fungal Identification Manual [13]. Then this newly isolated strain was named T. virens ZY-01 and deposited in the China Center for Type Culture Collection (CCTCC) with an accession number CCTCC M 2012205. Its $18 \mathrm{~S}$ rDNA sequence was deposited at the GenBank database with the Accession No. JX121089. The cellulase productivity of this newly isolated $T$. virens is appealing compared to the previous reports [11,16-18]. According to these reports, the cellulase activity was about 7.8, 0.18, 1.43 and $7.51 \mathrm{IU} / \mathrm{mL}$ to the corresponding T. reesei, Mutated T. viride, Fusarium oxysporum H57-1 and Rhizopus stolonifer var. reflexus TP-02 at the optimized enzyme production conditions.

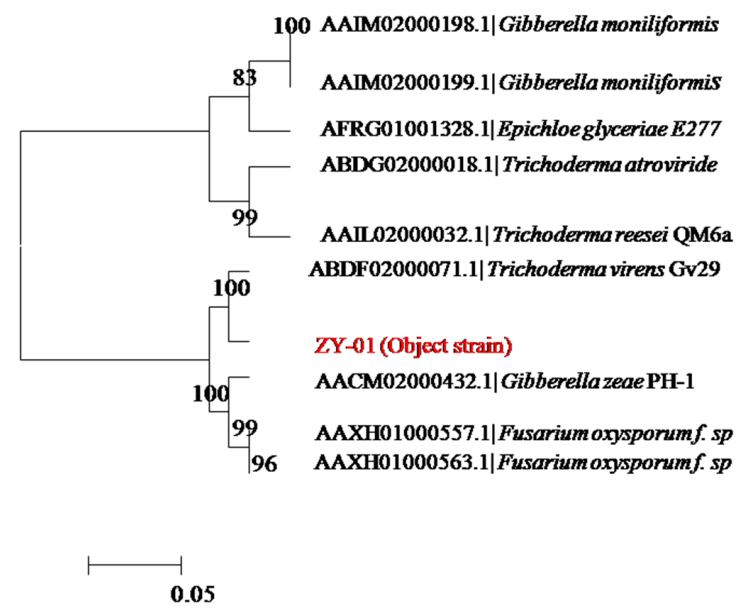

Figure 1. Neighbor-joining phylogenetic tree of $18 \mathrm{~S}$ rDNA genes of strain ZY-01.

\subsection{Purification of the Cellulase from the Newly Isolated T. virens ZY-01 Culture Broth}

The cellulase was purified from the cultivation broth of T. virens ZY-01. With three complementary purification steps (fractional precipitation, anion exchange chromatography and gel filtration chromatography) Sephadex G-75 chromatography elution was distinguished by molecular weight of protein. The elution curves are shown in Figure 2. The CMCase activity mainly assembled at peak II.

As a result, cellulase was purified 35.8 -fold with a $47.04 \%$ CMC enzymatic activity yield compared to the crude enzyme. The results of each separation step are given in Table 2.

Table 2. Results for purification of cellulose from T. virens ZY-01 culture broth.

\begin{tabular}{cccccc}
\hline Procedure & $\begin{array}{c}\text { Protein } \\
\text { Content/mg }\end{array}$ & $\begin{array}{c}\text { Enzyme } \\
\text { Activity/IU }\end{array}$ & $\begin{array}{c}\text { Specific } \\
\text { Activity IU/mg }\end{array}$ & Yield \% & $\begin{array}{c}\text { Purification } \\
\text { Fold }\end{array}$ \\
\hline Crude enzyme & 197.3 & 174.1 & 0.88 & - & - \\
\hline $\begin{array}{c}\text { Fractional } \\
\text { precipitation }\end{array}$ & 21.6 & 135.3 & 6.26 & 77.7 & 7.11 \\
\hline $\begin{array}{c}\text { Anion exchange } \\
\text { chromatography }\end{array}$ & 15.8 & 106.4 & 6.73 & 61.1 & 7.65 \\
\hline Gel chromatography & 2.6 & 81.9 & 31.5 & 47.04 & 35.8 \\
\hline
\end{tabular}




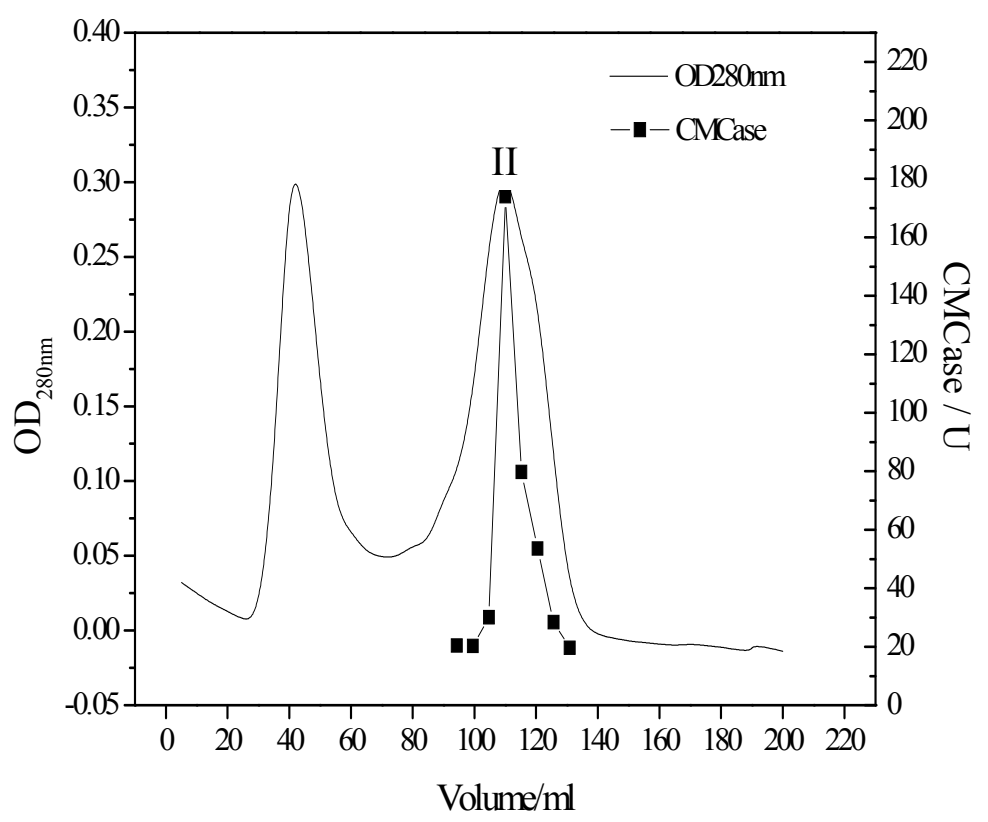

Figure 2. Elution profile gel filtration column chromatography.

The SDS-PAGE of the purification product was given in Figure 3. The SDS-PAGE result showed that there were three protein bands with molecular masses of $62 \mathrm{kDa}, 58 \mathrm{kDa}$ and $16 \mathrm{kDa}$. It indicates that this cellulase is a triple-subunit complex. In general, cellulase is multi-subunit complex. Tang and Balasubramanian respectively reported cellulases from Rhizopus stolonifer var. reflexus TP-02O and Bacillus mycoides S122C also had three subunits $[17,18]$. The molecular masses of the subunit are from $40 \mathrm{kDa}$ to $64 \mathrm{kDa}$.

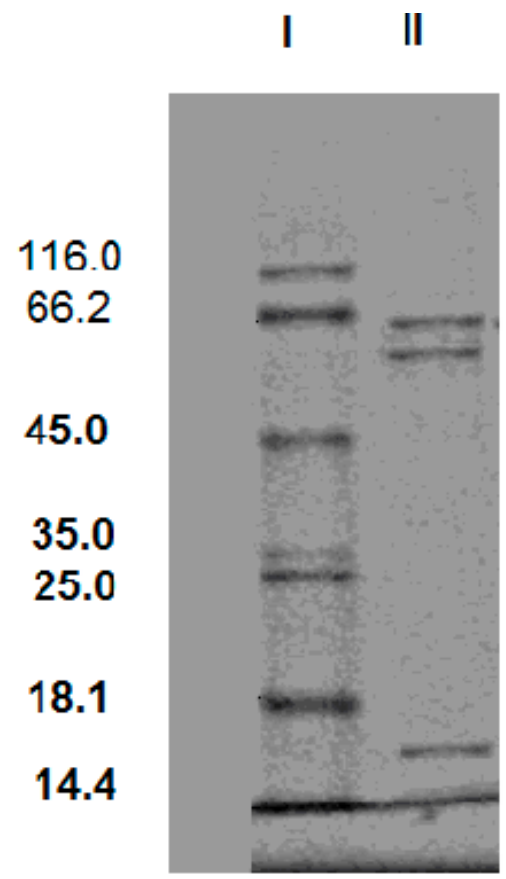

Figure 3. SDS-PAGE of the purification product from the T. virens ZY-01 cultivation broth. Lane I: protein ladder ( $\beta$-galactosidase $116.0 \mathrm{kDa}$, bovine serum albumin $66.2 \mathrm{kDa}$, ovalbumin $45.0 \mathrm{kDa}$, lactate dehydrogenase 35.0 kDa, REase Bsp981 25.0 kDa, $\beta$-lactoglobulin 18.1 kDa, lysozyme 14.4 kDa), Lane II: purification product. 


\subsection{Enzymatic Properties of Cellulase Produced by T. virens ZY-01}

The enzymatic properties are the fundamental bioinformation to an enzyme. They are important to it application. The following enzymatic properties of the new cellulase produced by $T$. virens ZY-01 were evaluated: the effect of reaction temperature, $\mathrm{pH}$ and metal ions to enzymatic activity, the thermal stability and $\mathrm{pH}$ stability. The corresponding results are present in Figures $4-8$. Figure 4 showed that the CMCase activity was highest at $60^{\circ} \mathrm{C}$ as protein degenerated gradually at a higher temperature. Figure 5 showed that the enzyme kept $90 \%$ of activity at $40{ }^{\circ} \mathrm{C}$ to $50{ }^{\circ} \mathrm{C}$, the remained CMCase activity decreased obviously when higher than $50^{\circ} \mathrm{C}$. Figure 6 showed that the activity increased sharply from $\mathrm{pH}=2.0$ to 4.0 , when $\mathrm{pH}$ is higher than 6.0 , the activity decreased, so the optimum reaction $\mathrm{pH}$ is 6.0. Figure 7 showed that the CMCase activity of cellulase remained stable at the range of 5.0-6.0, the activity could keep $80 \%$. If $\mathrm{pH}<5.0$ or $\mathrm{pH}>6.0$, the CMCase activity decreased, and the cellulase was sensitive to $\mathrm{pH}$. Figure 8 showed that $\mathrm{Zn}^{2+}, \mathrm{Ca}^{2+}$ and $\mathrm{Mn}^{2+}$ help cellulase while $\mathrm{Co}^{2+}$ and $\mathrm{Cu}^{2+}$ inhibit the enzyme activity.

The temperature could speed up the reaction, but the activity of cellulase would fade along with the increasing temperature. The space structure of the enzyme would be destroyed when over an acidic or basic environment, causing the change of conformation, and the loss of enzyme activity. The results showed that the optimum reaction temperature and $\mathrm{pH}$ is $60{ }^{\circ} \mathrm{C}$ and $\mathrm{pH}$. As the component of cellulase is protein, its structure is unique, and metal ions carry more than one positive charge, its effect is stronger than proton. Besides, metal ions have a complexing action, which could maintain the concentration of solution at a stable stage. Therefore, metal ions can clearly affect cellulase activity. The results showed that $\mathrm{Zn}^{2+}, \mathrm{Ca}^{2+}$ and $\mathrm{Mn}^{2+}$ are its activators; they can significantly promote its activity. The relative enzyme activity is respectively about $139.2 \%, 125.5 \%$ and $131.4 \%$ to the blank. In contrast, $\mathrm{Co}^{2+}$ and $\mathrm{Cu}^{2+}$ can obviously inhibit its activity. The relative enzyme activity is just $17.6 \%$ and $5.9 \%$ to the blank, respectively. It also can be seen that the stability of this cellulase is perfect. Even it was incubated at $50{ }^{\circ} \mathrm{C}$ for $1 \mathrm{~h}$, the residual activity can maintain it at $90 \%$. Since it was stored in $\mathrm{pH} 5$ buffer for $24 \mathrm{~h}$, its residual activity was about $85 \%$. These enzymatic properties of the newly obtained cellulase are similar to the cellulase from Bacillus mycoides S122C [18].

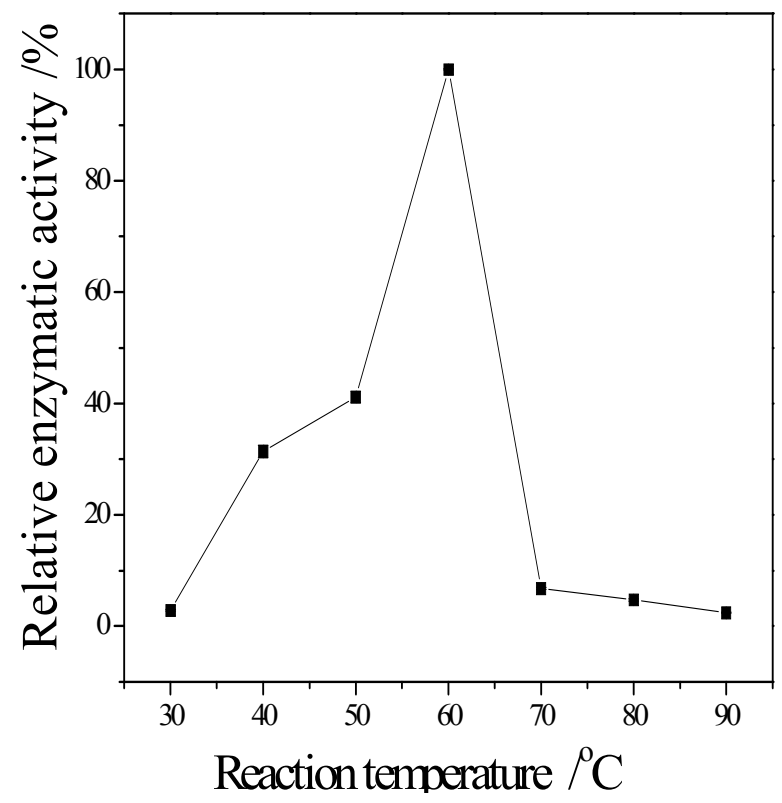

Figure 4. Effect of reaction temperature on enzymatic activity. 


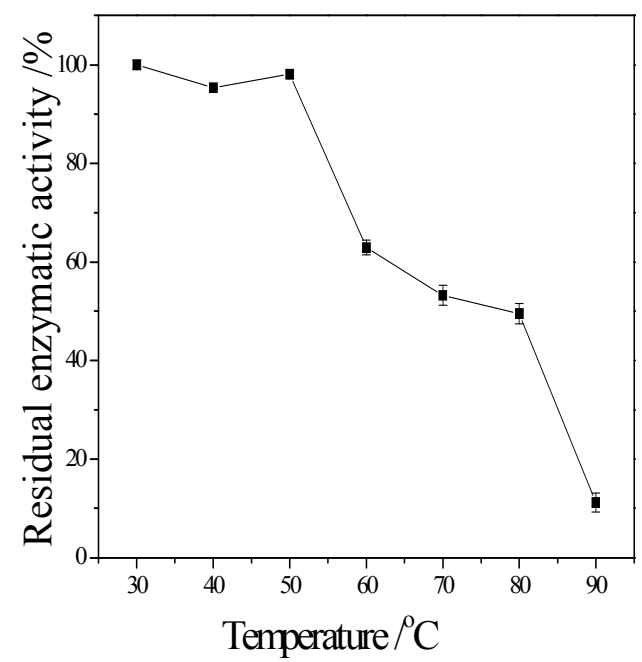

Figure 5. Thermal stability of the cellulose.

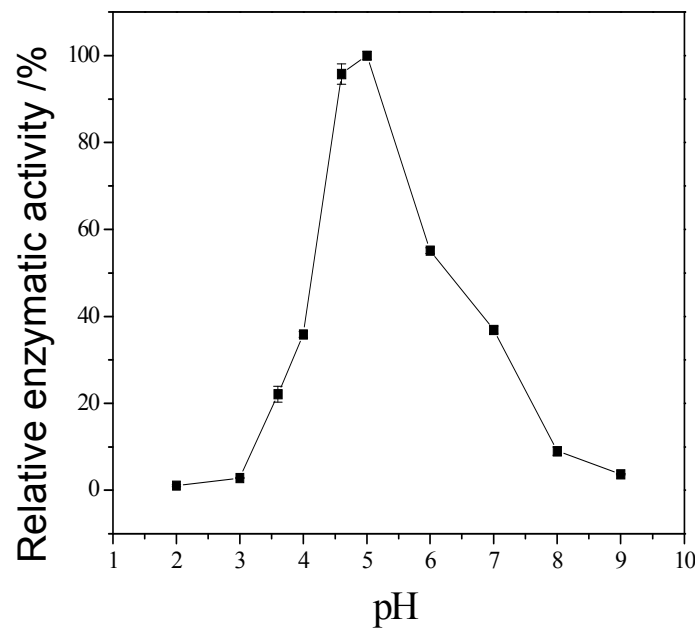

Figure 6. Effect of reaction $\mathrm{pH}$ on enzymatic activity.

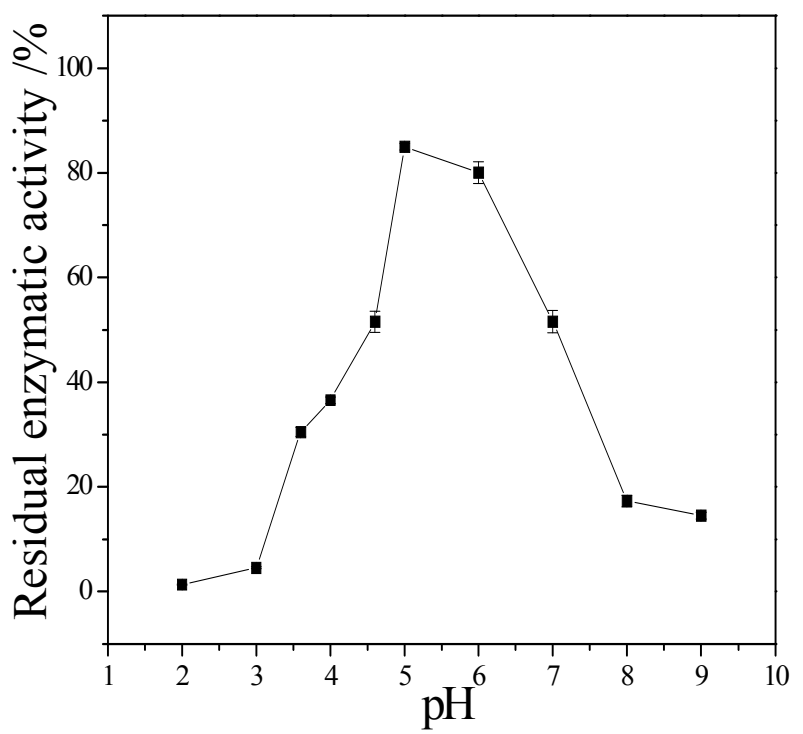

Figure 7. Stability of the cellulase to $\mathrm{pH}$. 




Figure 8. Effects of metal ions on enzymatic activity.

\section{Discussion and Conclusions}

Trichoderma virens produced enzyme activity is up to $31.5 \mathrm{U} / \mathrm{mg}$. This is high compared with Fusarium Oxysporum, which produced cellulase, and its enzyme activity was only $1.43 \mathrm{IU} / \mathrm{mL}$ [19], and Aspergillus sydowii, the CMCase of which was $1.32 \mathrm{IU} / \mathrm{mL}$ [20].

A novel Trichoderma virens was isolated from straw cropland. It can secrete high activity cellulase. The cellulase is a triple-subunit complex with molecular masses of 62,58 and $16 \mathrm{kDa}$ of each subunit. The optimum temperature and $\mathrm{pH}$ of the cellulase are $50{ }^{\circ} \mathrm{C}$ and $\mathrm{pH} 5.0 . \mathrm{Zn}^{2+}, \mathrm{Ca}^{2+}$ and $\mathrm{Mn}^{2+}$ could remarkably promote the enzyme activity. Conversely, $\mathrm{Cu}^{2+}$ and $\mathrm{Co}^{2+}$ are strong inhibitors to the cellulase. It possesses good stability in terms of thermal and $\mathrm{pH}$ factors. Based on these findings, it can be concluded that this newly obtained microbe is a good prospect for practical cellulase production and has good application for the new cellulase.

The Trichoderma virens ZY-01 was isolated for its high yield of cellulase, which is expected to be useful for hydrolysis of cellulosic and hemicellulosic substrates at proper temperatures, particularly for converting biomass into biofuels, to solve the energy crisis and the environmental pollution problem.

Acknowledgments: This study was supported by the National Natural Science Foundation of China (Grant No. 21376184), the Scientific Research Foundation for the Returned Overseas Chinese Scholars (State Education Ministry), the Foundation from Educational Commission of Hubei Province of China (Grant No. D20121108) and the Innovative Team of Bioaugmentation and Advanced Treatment on Metallurgical Industry Wastewater.

Author Contributions: Rong Zeng and Zhong-Hua Yang conceived and designed the experiments; Rong Zeng, Xiao-Yan Yin and Tao Ruan performed the experiments; Hao Huang and Ya-Li Hou analyzed the data; Zhen-Yu Zuo contributed reagents/materials/analysis tools; Qiao Hu and Zhong-Hua Yang wrote the paper.

Conflicts of Interest: The authors declare no conflict of interest.

\section{References}

1. Jeya, M.; Zhang, Y.-W.; Kim, I.-W.; Lee, J.-K. Enhanced saccharification of alkali-treated rice straw by cellulase from Trametes hirsuta and statistical optimization of hydrolysis conditions by RSM. Bioresour. Technol. 2009, 100, 5155-5161. [CrossRef] [PubMed]

2. Back, S.C.; Kwon, Y.J. Optimization of the pretreatment of rice straw hemicellulosic hydrolyzates for microbial production of xulytol. Biotechnol. Bioprocess Eng. 2007, 12, 404-409. [CrossRef]

3. Delmer, D.P.; Haigler, C.H. The regulation of metabolic flux to cellulose, a major sink for carbon in plants. Metab. Eng. 2002, 4, 22-28. [CrossRef] [PubMed] 
4. Olsson, L.; Hahn-Hagerdal, B. Fermentation of lignocellulosic hydrolsates for ethanol production. Enzym. Microb. Technol. 1996, 18, 312-331. [CrossRef]

5. Ramos, L.P.; Nahzad, M.; Saddler, J.N. Effect of enzymatic hydrolysis on the morphology and fine structure of pretreated cellusolic residues. Enzym. Microb. Technol. 1993, 15, 821-831. [CrossRef]

6. Bothwell, M.; Daughhete, S.; Chaua, G. Binding capacilities for Thermonmonspora fusca E-3, and E-4. The E-3 binding domain and Trichoderma reesei CBHI on avicel and bacterial microcryrstallie cellulose. Bioresour. Technol. 1997, 60, 169-178. [CrossRef]

7. Hii, K.-L.; Yeap, S.-P.; Mashitah, D.M. Cellulase production from palm oil mill effluent in Malaysia economical and technical perspectives. Eng. Life Sci. 2012, 12, 7-28. [CrossRef]

8. Kuhad, R.C.; Gupta, R.; Singh, A. Microbial cellulases and their industrial applications. Enzym. Res. 2011, 2011, 280696. [CrossRef] [PubMed]

9. Lin, Y.; Wei, W.; Yuan, P. Screening and identification of cellulase-producing strain of Fusarium oxysporum. Procedia Environ. Sci. 2012, 12, 1213-1219.

10. Assareh, R.; Shahbani, H.Z.; Akbari, K.N.; Aminzadeh, S.; Bakhshi, G.K. Characterization of the newly isolated Geobacillus sp. T1, the efficient cellulase-producer on untreated barley and wheat straws. Bioresour. Technol. 2012, 120, 99-105. [CrossRef] [PubMed]

11. Li, X.H.; Yang, H.J.; Roy, B.; Park, E.Y.; Jiang, L.J.; Wang, D.; Miao, Y.G. Enhanced cellulase production of the Trichoderma viride mutated by microwave and ultraviolet. Microbiol. Res. 2010, 165, 190-198. [CrossRef] [PubMed]

12. Zhao, Y.; Chen, G.; Zhou, W.; Hou, Y.; Yang, Z. Progress of cellulase and cellulase gene research. Biotechnol. Bull. 2013, 2013, 35-40. (In Chinese)

13. Fungal Identification Manual; Wei, J.C., Ed.; Shanghai Science and Technology Press: Shanghai, China, 1979. (In Chinese)

14. Xue, S.J.; Yue, T.L.; Yuan, Y.H.; Gao, Z.P. An improved method for extracting fungal DNA. Food Res. Dev. 2006, 27, 39-40. (In Chinese)

15. Dashtban, M.; Maki, M.; Leung, K.T.; Mao, C.; Qin, W. Cellulase activities in biomass conversion measurement methods and comparison. Crit. Rev. Biotechnol. 2010, 30, 302-309. [CrossRef] [PubMed]

16. Saravanan, P.; Muthuvelayudham, R.; Viruthagiri, T. Application of statistical design for the production of cellulase by Trichoderma reesei using mango peel. Enzym. Res. 2012, 2012, 157643.

17. Tang, B.; Pan, H.; Tang, W.; Zhang, Q.; Dinga, L.; Zhang, F. Fermentation and purification of cellulase from a novel strain Rhizopus stolonifer var. reflexus TP-02. Biomass Bioenergy 2012, 36, 366-372. [CrossRef]

18. Balasubramanian, N.; Toubarro, D.; Teixeira, M.; Simõs, N. Purification and biochemical characterization of a novel thermo-stable carboxymethyl cellulase from azorean isolate Bacillus mycoides S122C. Appl. Biochem. Biotechnol. 2012, 168, 2191-2204. [CrossRef] [PubMed]

19. Yuan, L.; Wang, W.; Pei, Y.; Lu, F. Screening and Identification of Cellulase-Producing Strain of Fusarium Oxysporum. Procedia Environ. Sci. 2011, 12, 1213-1219. [CrossRef]

20. Ketna, M.; Digantkumar, C.; Jyoti, D.; Anand, N.; Datta, M. Production of cellulase by a newly isolated strain of Aspergillus sydowii and its optimization under submerged fermentation. Int. Biodeterior. Biodegrad. 2013, 78, 24-33.

(C) 2016 by the authors; licensee MDPI, Basel, Switzerland. This article is an open access article distributed under the terms and conditions of the Creative Commons Attribution (CC-BY) license (http://creativecommons.org/licenses/by/4.0/). 